\title{
Three significances of the notion heritage: a study of the dissonance between institutionalization, tourism image and social perceptions in rural areas
}

\author{
José David Albarrán Periáñez* \\ Investigador independiente (España)
}

\begin{abstract}
This paper explores the different meanings that heritage has for conservation, tourism and local identity. Based on an in-depth examination of a conceptual framework, heritage was seen to have three different meanings: (i) the one recognized at the institutional level by administrations concerned with the protection of assets and spaces; (ii) the one that is based on the configuration of the image of the land within the tourism sector; and (iii) the one that corresponds to the sense of identity of the local people in that community. The aim of this research is to identify the relationships between these significances in order to contribute toward improved heritage management. To this end, an empirical methodology was configured based on standard techniques in social sciences, including an analysis of the content of public policies, a semiotic analysis of the tourism image and consultation using questionnaires. This methodology makes it possible to isolate the different variables and determine how the synergies between them are made manifest within a specific rural context, and then predict how these impacts can be replicated elsewhere. Based on our results, the conclusion is that more heterogeneous values of heritage need to be incorporated into both the tourism image and the social perception, using the latest academic approaches. It also shows that the traditional segmentation of administrative frameworks prevents a similar development within the existing institutional contexts.
\end{abstract}

Keywords: Heritage; Institutionalization of Heritage; Tourism image; Social perception.

Tres significaciones del patrimonio: estudio de las disonancias entre la institucionalización, la imagen turística de los destinos y las percepciones sociales en el ámbito rural

Resumen: Este trabajo aborda los diferentes significados que actualmente tiene el patrimonio en la conservación, la industria turística y la identidad local. A partir de un profundo análisis del marco conceptual se determina que el patrimonio presenta tres significaciones diferenciadas: (i) la reconocida a nivel institucional por las administraciones con competencias en la protección de bienes y espacios; (ii) la basada en la configuración de la imagen turística del territorio; y (iii) la que se corresponde con el punto de vista de la comunidad que lo posee. El objetivo de esta investigación es identificar las relaciones que se establecen entre ellas con objeto de contribuir a una mejor gestión patrimonial, y para ello se configura una metodología empírica basada en técnicas estándar para las ciencias sociales como un análisis del contenido de las políticas públicas, un análisis semiótico de la imagen turística y un proceso de consultas mediante cuestionarios. Este modelo metodológico permite estudiar las diferentes variables y determinar cómo son las sinergias que se establecen entre ellas en un contexto rural específico, al tiempo que puede ser replicado en otros lugares. Como resultado, las conclusiones sugieren que valores más heterogéneos del patrimonio han sido incorporados tanto a la configuración de la imagen turística como a la propia percepción social, siguiendo los planteamientos académicos más recientes. Sin embargo, la tradicional segmentación de los marcos administrativos impide un desarrollo similar en el contexto institucional actual.

Palabras Clave: Patrimonio; Institucionalización del patrimonio; Imagen turística; Percepción social.

Investigador independiente (España); E-mail: josedalb@ucm.es; https://orcid.org/0000-0002-4774-9639 


\section{Introduction}

From an etymological point of view, and even in the definitions found in dictionaries, the term heritage refers to what humans receive from the past that they hold in trust in the present time and which can be transmitted to the future. Despite these definitions, there are considerable discussions associated with this concept which may affect the way heritage is actually understood and managed. To begin with, most scholars argue that the current idea is based on a social definition as expressed in the total knowledge, beliefs and values of a community with a certain desire for preserving and perpetuating them (Ballart \& Tresserras, 2008; Fernández \& Guzmán, 2004; Almirón et al., 2006; Silva, 2009; Llull, 2005). Inside this approach, the existence of a society is needed in order to shape the patrimonial dimension of any resource. Consequently, heritage becomes a primarily social construction (Ozouf-Marignier, 2010).

In this regard, some authors define the valuation of heritage from the existence of a linear process that, in general terms, goes from (i) the identification of values, to (ii) the subsequent establishment of the means for protecting and safeguarding, and finally (iii) the definitive development of conditions of use (Feria, 2010; Calderón \& García, 2016a, 2016b). In this valuation, however, there is certainly a need to distinguish between two different operations that shape heritage: one in which heritage is built from the bottom up; and the other, in which heritage is constructed form the top down (Prats, 1997; Carta, 2010; Gómez, 2013; Silva \& Fernández, 2017). The first refers to a social process focused on the legitimation of a selection of elements through the assignment of values by a group of people (e.g. a community), who see them as a part of their identity. For its part, the second process consists of a series of legal procedures implemented by public administrations characterized by universality, irrevocability and transferability (e.g. the adoption of protection laws and the establishment of inventories). Nonetheless, in spite of the existence of both operations in most studies, the need to fulfil the second link in the process of valuing heritage (i.e. concerning the creation of protective tools) implies that authorities will ultimately define the formal process of "patrimonialization" (Prats, 1997; Smith, 2006; Medina, 2017). In this way, institutions determine what heritage is within the current regulatory framework, basing their decisions on the knowledge of experts (Smith, 2006), and justifying their selections as having an important meaning for the community (Monteserín, 2008). Therefore, public entities shape a patrimonial discourse defined as authorized (Graham et al., 2000; Santana, 2003; Troncoso, 2013), which has occurred since the establishment of the primary laws and administrative bodies for the protection of historical and natural heritage at the beginning of the last century (Castillo, 2009). From there, public agents legitimize the importance and symbolism of heritage in creating the collective identity (Medina, 2017).

Consequently, given the need to consider the third link in this process, the tourism industry has been consolidated as one of the most common tools for giving heritage a useful function. Therefore, in the current context, where tourism is understood as an effective instrument for the development of territories, heritage becomes a key factor in the creation of unique and singular products through the exploitation of assets (Castro \& Rodrigues, 2017; Huete \& López, 2019). At this point, a reciprocal relationship is created as tourism promotes the conservation and preservation of assets (Troitiño, 2003; Troitiño \& Troitiño, 2015), while these assets become singular elements to attract visitors (Troncoso, 2013; Bertoncello, 2015). In this sense, one of the main duties of local authorities is to use assets to configure tourism images, for which studies have gained considerable attention in the framework of tourism research (see Batista et al., 2020). In this respect, there is some consensus on the idea that the tourism image of a destination is a crucial factor in the decision process by potential visitors (Goodrich, 1978; Woodside \& Lysonski, 1989; Andreu et al., 2000; Perelló, 2006; Edelheim, 2007; San Martín \& Rodríguez, 2008; Picón et al., 2013; Castro \& Rodrigues, 2017; Piramanayagam et al., 2020). Today, however, in an increasingly globalised and competitive world, the simplification in the creation of tourism images can bring the generation of stereotypes (Pearce, 1988; Santos, 2008) that may have an influence on the perception of the land not only by tourists, but also by the locals living at that destination (Alvarado-Sizzo et al., 2018). It is this that may also entail a substantial alteration of the reality (Hernández, 2008). This is because, according to Relph (1976), economic efficiencies are privileged over experiences in the recent transformation of places derived, among other factors, from increased mobility. Thus, what we are witnessing is a change in the perspective through which human beings understand places, where opportunities for development are being superimposed upon identity values.

In this regard, questions should be raised about how the use of assets in the configuration of the image that is being portrayed to tourists could entail a change in the perception by locals about their place of residence; or indeed, whether the prevalence of a segmented approach in the institutional framework 
is reflected in the social perspective of place. The first assumption would oblige the local community to recognize its most representative assets. This iconic aesthetic, assumed by the collective imagery as a part of their heritage, occurs regardless of whether they have been accepted by administrations with the authority to manage heritage resources or not. The other assumption would involve questioning the effectiveness of public policies when contrasted with their lack of consistency with the popular will. This phenomenon becomes critical when considering globalization, as some locations begin weakening their own identity by becoming homogeneous (Maderuelo, 2006). This phenomenon is especially important in remote, rural areas where traditions and living expressions inherited from ancestors still prevail, while the tourism industry remains increasingly focused on authenticity (Katahenggam, 2019). Despite the significance of this issue, the existing body of literature is still limited as academics have not paid sufficient attention its exploration. This is precisely the fundamental objective of the current investigation, which aims to detect the synergies established between the different significances of heritage to contribute to a reflection on how to build more effective management models.

Hence, this paper seeks to illustrate the need for more empirical and theoretical scrutiny in the evaluation of the convergences and discords that exist between the protection of heritage and the promotion of tourism, since both these factors have a significant impact on the social valuation of heritage. Thus, after an in-depth study of this matter on a theoretical level, a critical observation of the different significances of heritage was carried out at a location characterized by rural isolation, mainly Sierra de Cádiz.

Sierra de Cádiz is a district with an enormous wealth of heritage, and embodies a paradigm in the projection of Andalusian and Spanish idealism in Western imagery. To that end, a public policy analysis was developed to study how heritage is integrated into the operative instruments launched by institutions with competences for heritage protection, determining when, to what extent, and how differently the categories of resources have been assigned and catalogued. Secondly, through a semiotic analysis of images, we propose to systematise and objectively analyse the visual information included in promotional materials edited by local authorities, and in this way, dissect the construction of the tourism image. Finally, a survey is conducted to assess what the most important heritage assets contributed by local residents actually are. In so doing, we can verify how a traditional view that prioritizes historic, artistic or ecological values continues to prevail within the catalogues. By contrast, the latest academic approaches to heritage, presented in both the tourism image promoted by local authorities as well as the contributions made by the local community, enhances these heritage assets with a broader territorial meaning.

\section{Literature review}

During the last few decades, there has been a change from a context dominated by industrial production to a new economic model where territories have to compete to make a name for themselves inside the neoliberal globalization framework. This phenomenon implies a shift from a context characterized by homogeneous and standardized spaces (Torres \& Momsen, 2005; Carrera, 2005), or even the "inauthentication" of places (Relph, 1976), to a revaluation of qualitative, symbolic and cultural aspects of the land (Pine \& Gilmore, 1998, 2011; Bianchi, 2017). This generates the reinforcement of development policies based on singular resources, augmenting the significance of the land (Bianchi, 2017) and increasing the sense of place through emotional or cultural values (Arefi, 1999; Zwiers et al., 2018). In this regard, heritage contributes to the emergence of new opportunities for territorial development, particularly through the use and exploitation of assets in the tourist industry. In so doing, heritage has moved from being a burden on the economy to being understood as a competitive resource in the postmodern economy (Graham et al., 2000; McCrone et al. cited by Harvey, 2019), passing from the simple contemplation and preservation of assets and spaces to their understanding as a productive resource (Laven et al., 2005; Mata, 2008).

This theory is widely discussed within the academic world and is aligned with the very concept of heritage, whose characterization is subject to the conditions derived from prevailing philosophical, political or cultural trends, which implies that it has had different definitions throughout history (Laven, 2015; Harvey, 2019). The idea of heritage, indeed, is a subjective and symbolic selection of elements that are adapted or reinvented from the present and projected towards posterity by human beings (Graham et al., 2000; Almirón et al., 2006; González-Varas, 2014; Medina, 2017; Troitiño \& Troitiño, 2018; Hewison cited by Harvey, 2019). This invites the consideration of heritage as a product 
of a society. With that in mind, academic consensus widely accepts the idea that a sense of collective belonging is implicit in the concept of heritage, as is the existence of a social concern to both preserve and transmit its values (Ortega; 1998; Silva, 2009; Vahí , 2010; Doctor, 2011; Bustos \& Pinassi, 2017; Román \& González, 2019). Hence, the process of patrimonialization is defined by an initial valuation and a subsequent articulation of preservation measures (Agudo, 1999); to which some authors have recently added a definitive attribution of uses (Feria, 2010; Calderón \& García, 2016a, 2016b).

In this respect, the continuous evolution of the concept of heritage has recently implied the overcoming of traditional heritage references, in parallel to its recognition as a developing resource (i.e. especially in economic terms). This means, first of all, that there has been an increasing approximation between cultural and natural heritage (Fernández 1998; Ballart \& Tresserras, 2001; Capel, 2014; Feria, 2010, 2013; Florido, 2013; Fernández \& Guzmán, 2004; Calderón \& García, 2016b; Castillo, 2007; López et al., 2017; Román \& González, 2019; Bridgewater \& Rotherham, 2019), as well as an incorporation of spatial perspectives in the contemporary literature about heritage, particularly in the field of geography (Ariño, 2002; Prats, 2005; Ortega, 1998; Troitiño, 1998, 2000, 2011; Castrillo \& Tremiño, 1998; Feria, 2010, 2013; Mulero, 2015; Troitiño \& Troitiño, 2015; Doctor, 2011; Manero \& García, 2016; Roque et al., 2019). This is considered the last step in the evolution of the idea of heritage, which begins by recognizing the exceptionality and singularity of the monument as a preferential heritage object, and moves towards the inclusion of urban, immaterial or environmental dimensions throughout the whole of the $20^{\text {th }}$ century (Castillo, 2009; Gómez, 2013; Martínez, 2008). This process has concluded in what has come to be known as territorial heritage in the Spanish-Latino literature, which requires moving from the typically segmented view espoused during the Enlightenment to the integration of environmental, social and territorial dimensions in current concepts of heritage. However, traditional Western approaches based on structured categories and dichotomies (Relph, 2000; Wall-Reinius, 2012) continue to be present in legal frameworks and policy instruments. This fact hints at understanding nature and culture separately (Bridgewater \& Rotherham, 2019), while managing them in isolation.

Concurrently, this particular evolution of the concept implies the recognition of an evolving dimension that is linked to heritage. Many authors agree that new approaches to heritage carry a shift from protection to enhancement (Feria, 2013), where consequently, heritage becomes recognised as a catalyst for economic and social development (López et al., 2017; Amat, 2018; Martínez, 2008; Castrillo \& Tremiño, 1998; Mulero, 2015; Molina \& Pascual, 2016; Maurín, 2011; Castillo, 2007; Rodríguez \& Sevilla, 2017; Martínez, 2008; Calderón \& García, 2016b). In this sense, some authors note its significance as an economic resource susceptible to exploitation, among other impacts, through tourist activity (Pillet, 2011, 2012; Fernández \& Guzmán, 2004; Martínez, 2008; Troitiño \& Troitiño, 2018). This process involves the commodification of heritage in the tourism sector (Katahenggam, 2019) as defined by its commercial aspects, and its eventual portrayal as a "hostage to the whims of leisure fashion" (Harvey, 2019, p.5). However, to make this relationship effective, it is necessary to transform assets into products through capitalist production techniques (Britton, 1990), which involves two different aspects: that of the market, which pursues profitability from a short-term viewpoint; and that of culture, focused on the defence of asset value from an eminently cultural focus (Velasco, 2009). In response to this relationship, the International Council on Monuments and Sites (ICOMOS) adopted the International Cultural Tourism Charter in 1999. This is the first international charter that specifically includes a complex list of principles for finding effective interrelationships between heritage and tourism as an impetus to conserving assets like tourist attractions. Since then, more and more academic and institutional references document the need to configure an overall strategy to plan and manage heritage tourist destinations (UNWTO, 1985; UN, 1992; ICOMOS, 1999; UNWTO \& UNESCO, 2015, 2017, 2018).

Despite being a complex task, the fact that these interests have been combined, has consolidated heritage as the main element around which to build the projected tourism image of destinations. In the current context, which is primarily visual, the promotion of a locality is vital in differentiating one place from another (Britton, 1990; San Martín et al., 2006; Novo et al., 2013; Castro \& Rodrigues, 2017; Mehmood et al., 2018; Huete \& López, 2019), and the use of heritage ensures the diffusion of a unique image for each place (Piramanayagam et al., 2020). This fact has made governments generate tourism images based on heritage. However, some studies have shown that the characterization of places is the result of the overall demand of tourists (Prats, 1997; Almirón, et al., 2006), which is formed through a selection of key symbols that provide easy recognition (Rodríguez et al., 2012; Novo et al., 2013). Thus, although significant efforts have recently been made to diversify tourism images (Hernández, 2008), 
the need to reaffirm the singularities of destinations necessarily reinforces clichés. In other words, landmarks that are generally promoted by administrations tend to convey a stereotypical image of that area in an attempt to display a more attractive image for potential visitors (Troncoso, 2010; Bertoncello, 2015; Katahenggam, 2019). Thus, attributes used in tourism image often reflect external interests, as the most representative icons of each destination are repeatedly perpetuated, a process that blossomed in European travel literature during the eighteen and nineteen centuries. Ultimately, tourism images are based on iconic and easily recognizable icons.

Based on this, public administrations have become essential for the efficient management of heritage and tourism because (i) they are responsible for the cataloguing and protection of assets (i.e. from both the cultural and natural standpoints), while (ii) having the authority to market the land as a destination by promoting the unique values of heritage. In this way, both the cataloguing of assets and their touristic exploitation become parallel processes (Cors et al., 2018), which can result in an increase in the capacity of tourism to establish itself as an identity reference for the society that reveres heritage (Graham et al., 2000).

Consequently, consideration needs to be given to the idea that tourism can indeed influence not only the perception of visitors (Richardson \& Crompton, 1988; San Martín, 2005; Berger \& Luckmann, 1986; Hiernaux, 2002), but the perception of locals as well (Urry, 2002; Edelheim, 2007; Hernández, 2008; García \& Mercado, 2019). This phenomenon may influence and eventually imply the weakening of current identities of place in an increasingly competitive and globalized world. If economic processes are prioritised, the adaptation of assets to the tourist market may lead to a significant redefinition of spatial quality through the potentialities given by the materiality of space for the creation of wealth, regardless of its symbolic interpretations. In this way, and as early as the end of the last century, Prats (1998) affirmed that tourism can actually play a key role in patrimonialization processes, while Relph (1976) argued that tourism could even stimulate the complete destruction and eventual replacement of perceived local landscapes.

Because of it, it is essential to articulate an analysis that can help to identify convergences and discords between the significances of heritage gleaned from these different perspectives (e.g. institutional protection, tourism promotion, and social valuation), while understanding tourism as an instrument that has the potential to transform the perceived identity of communities. This process is crucial in isolated, rural, and poorly-developed places, where the incentives and support of European Union policies have largely focused on tourism development (Alebaki \& Koutsouris, 2019). And this, especially given that its active contributions have become a significant part of the economy (Huete \& López, 2019; Piramanayagam et al., 2020). Uncontrolled tourism development in these areas could potentially alter the way heritage is assimilated by authorities and consequently by the local population, entailing damaging consequences to social identity over time.

\section{Methodological approach}

This research aims to shed light on the relationships between the different significances heritage have on the current socio-economic context. The main objective of this study is to analyse the convergences and discords between cultural, tourist and identity approaches to heritage, and in so doing, attempt to determine if heritage values remain the same regardless of one's perspective or whether, on the contrary, they change. The consideration of heritage as an economic resource implies the assimilation of new capacities or utilities; and the dominance of economic processes in the current context could radically change the very meaning of this concept. For this reason, this study seeks to illustrate the need for more empirical and theoretical scrutiny in the evaluation of the convergences and discords that exist between the protection of heritage and the promotion of tourism, since both factors have a significant impact on the social appreciation of heritage. That is why, after this in-depth theoretical analysis, a case study examining the different significances of heritage will be conducted inside of a context characterized by rural isolation. Using quantitative techniques, this methodology strives to focus on the analysis of (i) the heritage protected by institutions with authority over cultural and environmental issues; (ii) the heritage used for the construction of tourism images; and (iii) the social perception of heritage. Hence, in this work the synergies that exist between the institutionalization of heritage and the use of it in the configuration of tourism images are elaborated using different techniques to test whether local identity is closer to one particular perspective than it is to another. 


\section{Table 1: Data collection methods and techniques}

\begin{tabular}{|c|c|c|c|}
\hline & Legal protection & Tourism image & Social identity \\
\hline Method & Public policy analysis. & Semiotic analysis. & $\begin{array}{l}\text { Quantitative analysis of } \\
\text { responses. }\end{array}$ \\
\hline Data sources & $\begin{array}{l}\text { Current catalogues and } \\
\text { inventories launched by } \\
\text { public institutions. }\end{array}$ & $\begin{array}{l}\text { Pictures included on } \\
\text { existing promotional } \\
\text { materials. }\end{array}$ & Structured questionnaires. \\
\hline $\begin{array}{l}\text { Facilitator of } \\
\text { information }\end{array}$ & $\begin{array}{l}\text { Regional ministries } \\
\text { responsible for cultural and } \\
\text { natural heritage. }\end{array}$ & $\begin{array}{l}\text { Provincial and local } \\
\text { administrations capable of } \\
\text { tourism promotion. }\end{array}$ & $\begin{array}{l}\text { Citizens over the age } \\
\text { of } 16 \text { in three different } \\
\text { municipalities. }\end{array}$ \\
\hline $\begin{array}{l}\text { Amount of } \\
\text { sources }\end{array}$ & $\begin{array}{l}16 \text { public catalogues and } \\
\text { inventories. }\end{array}$ & $\begin{array}{l}545 \text { images extracted } \\
\text { from } 64 \text { videos, brochures } \\
\text { and guides edited by the } \\
\text { Provincial Tourism Council. } \\
240 \text { images extracted from } \\
28 \text { videos, brochures and } \\
\text { guides edited by three } \\
\text { different councils. }\end{array}$ & $\begin{array}{l}411 \text { responses to } \\
\text { questionnaires. }\end{array}$ \\
\hline
\end{tabular}

In order to begin, the legal protection of heritage, which is conditioned by the evolution of the concept in public regulations, requires a documented revision of the legal framework and political tools that effect heritage in a particular area. A public policy analysis then enables the determination of the specific criteria for the definition of heritage. To this end, a total of 16 catalogues and inventories launched by the institutions responsible for cultural and natural heritage are examined in the study area. This latter examination is done on the basis of the analysis proposed by Velasco (2007) for tourism policy. Accordingly, information about the assets and spaces that have been recognized by those national and regional administrations responsible for the management, safeguard and diffusion of heritage is examined. In this way, the dominant category may be determined to better understand how these criteria have evolved as well as how perspectives about them have been protected over time.

Concurrently, a study of the tourism image in the existing promotional materials is carried out to explore how heritage is used in tourism image construction. To this end, the presence of assets and spaces in the materials edited by the organisms responsible for tourism promotion at the provincial and local levels are analysed. The methodology implemented makes it possible to systematise and objectively analyse the visual information included within the promotional material in statistical terms. According to Picazo and Moreno-Gil (2017), this process is essential in the evaluation of the image projected by destinations, being constantly used by scholars (Buck, 1977; Thurot \& Thurot, 1983; Albers \& James, 1988; Dann, 1996; Dilley, 1986; Pritchard \& Morgan, 2001; Urry, 2002; Edelheim, 2007; Milman, 2011; Donaire \& Galí, 2011; Matteucci \& Önder, 2018). Thus, in this study the content of 545 images used in posters, videos, brochures, guides or official websites edited by provincial entities with competences for tourism promotion, and 240 images published by the local authorities during the last three decades are analysed. The results are demonstrated on a table indicating the frequency of use of the various assets and spaces as tourist attractions.

Finally, the social appreciation of heritage is determined through the implementation of a process based on citizen consultation. A questionnaire survey is conducted amongst the local population over 16 years of age (i.e. considered to be the minimum age limit for generating critical viewpoints about the issues described). The structured questionnaire was developed within the drafting process of several local plans, and the subsequent quantitative examination considered the answers to a specific question. This question was open-ended, mainly, "Please indicate what heritage resources are most important for your municipality's identity". Finally, a sample of 411 questionnaires was administered between March, 2017 and July, 2018 within three different municipalities.

These methods helped to identify the synergies between the different significances of heritage, and contributed to the formulation of an innovative and replicable new model of intervention. 


\section{Case study}

With an estimated population of 116,000 residents, Sierra de Cádiz is the northernmost district in the province of Cádiz in southern Spain. The district consists of 19 municipalities distributed between the Penibetic Mountains and the valley of the Guadalquivir River before it flows into the Atlantic Ocean. Over the past few decades, this district has become one of the most attractive rural destinations in Andalusia, increasing the relevance of the tourism sector in the local economy. Important topographical features which helped to foment the dramatic increase in tourism development and the subsequent multiplication of available accommodation in the area include $1,648 \mathrm{~m}$ high mountain peaks, cave paintings, ruins of Roman engineering works and cities, and small white villages located more than 600m above sea-level. Thus, the total number of beds in hotels grew from 609 in 1990 to 2,599 in 2019, while the current number of places in rural accommodation reaches 9,058 (Regional Ministry of Tourism, Regeneration, Justice and Local Administration, 2020).

Sierra de Cádiz has established itself as one of the most representative areas of Andalusia in Western imagery (Fernández et al., 2010). In addition to safeguarding their roots from the Arab Moorish Age, the tendency for concentrated population densities since that time has helped to avoid dispersed land occupation, enabling the conservation of wider natural spaces (Suárez, 1982).

Figure 1: Location of Sierra de Cádiz in the region of Andalusia, Spain

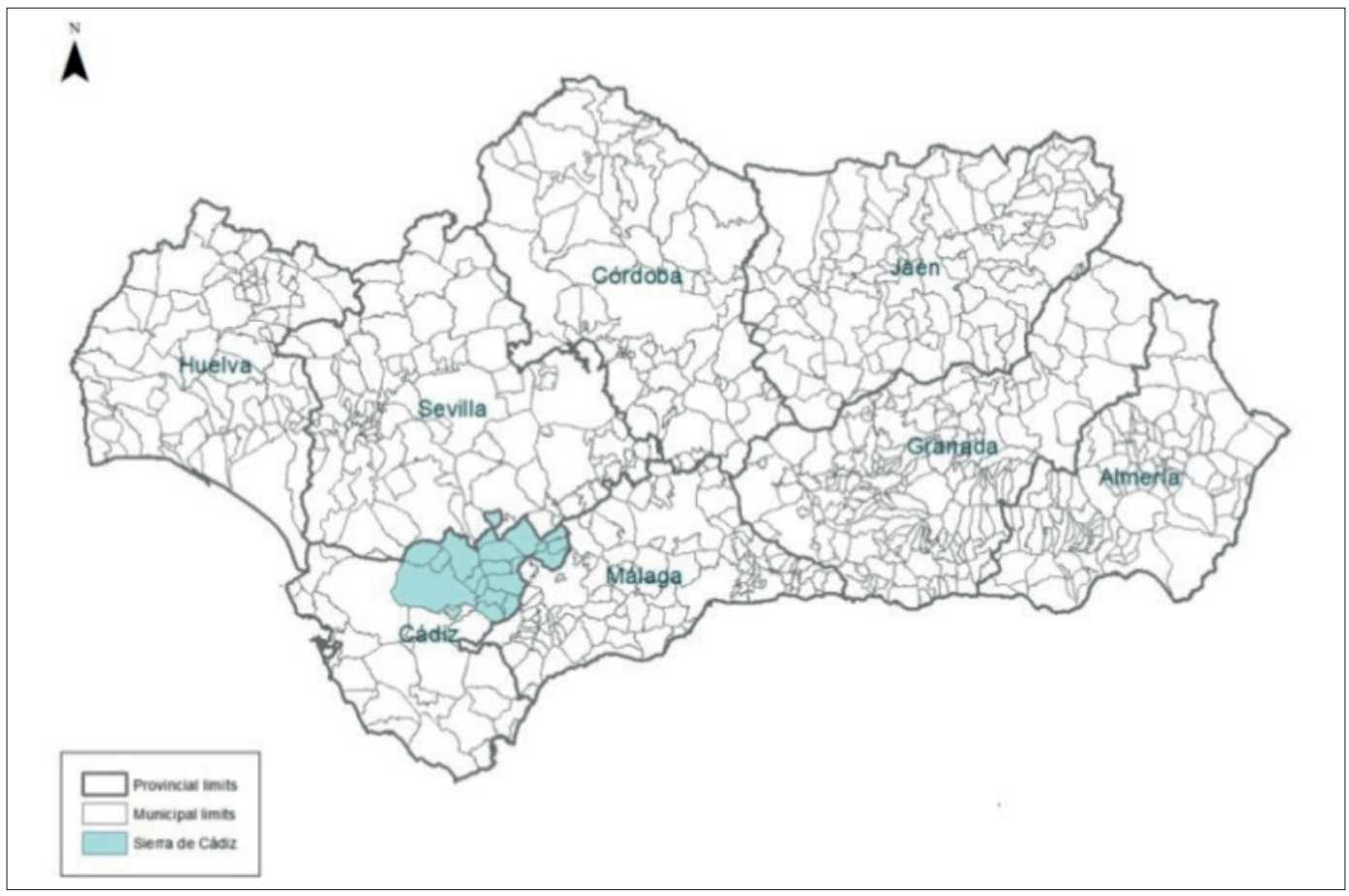

In order to develop this research, three municipalities were selected in the district according to the following criteria: demographic characteristics, number of accommodations, local tourism policy, or importance in the tourism image of the area, mainly (i) Grazalema, (ii) Olvera, and (iii) Setenil de las Bodegas. The three municipalities account for almost 20 percent of assets catalogued in the district for the highest level of protection by the national and regional administrations responsible for cultural heritage. These are also some of the most representative municipalities in terms of tourism capacity in the district, and together they represent over a quarter of the total available spaces of accommodation, with almost 11 percent of total tourist apartments in the entire province according to the Regional 
Ministry of Tourism, Regeneration, Justice and Local Administration. In addition, they are three out of the four municipalities in Sierra de Cádiz featured in the promotional posters edited by the National Ministry of Tourism, and the only three with tourism management plans at a local scale to date. All of this has helped to make these municipalities emerging visitor destinations, with enhanced services and infrastructure that cater to the image of the destination.

It is worth noting that the development of tourist activity has varied widely in each of these municipalities. Grazalema quickly benefited from Sierra de Grazalema being declared Biosphere Reserve and Nature Park during the 70s and 80s. For its part, tourism at Setenil de las Bodegas took-off much later and well into the $21^{\text {st }}$ century due to its location near the famous city of Ronda, and the need for tour operators and travel agents to extend their tracks. Olvera, with more significant industrial development and almost three times the population of the others, benefited from its location near a national road that is the main connection between the province of Cádiz and the rest of Andalusia.

The following table presents a descriptive compression of each municipality using various basic indicators related to geography, tourism, and heritage features.

Table 2: Heritage and Tourism: Comparison of Grazalema, Olvera and Setenil de las Bodegas

\begin{tabular}{|l|l|l|l|}
\hline & Grazalema & Olvera & Setenil de las Bodegas \\
\hline $\begin{array}{l}\text { Location and } \\
\text { height (m) }\end{array}$ & $\begin{array}{l}36^{\circ} 45^{\prime} 31^{\prime \prime} \mathrm{N} 5^{\circ} 22^{\prime} 09^{\prime \prime} \mathrm{O} . \\
913\end{array}$ & $\begin{array}{l}36^{\circ} 56^{\prime} 05^{\prime \prime} \mathrm{N} 5^{\circ} 15^{\prime} 36^{\prime \prime} \mathrm{O} . \\
643\end{array}$ & $\begin{array}{l}36^{\circ} 51^{\prime} 51^{\prime \prime} \mathrm{N} 5^{\circ} 10^{\prime} 53^{\prime \prime} \mathrm{O} . \\
640\end{array}$ \\
\hline $\begin{array}{l}\text { Total land area } \\
\left.\mathbf{k m}^{2}\right)\end{array}$ & 117,50 & 193,60 & 82,20 \\
\hline $\begin{array}{l}\text { Population } \\
\text { (2019) }\end{array}$ & 2.027 & 8.113 & 2.769 \\
\hline $\begin{array}{l}\text { Hospitality } \\
\text { infrastructure } \\
\text { (2019) }\end{array}$ & $\begin{array}{l}541 \text { beds in hotels \& } 846 \\
\text { beds in apartments }\end{array}$ & $\begin{array}{l}131 \text { beds in hotels \& } 342 \\
\text { beds in apartments }\end{array}$ & $\begin{array}{l}78 \text { beds in hotels \& } \\
452 \text { beds in apartments }\end{array}$ \\
\hline $\begin{array}{l}\text { Number of } \\
\text { visitors (2017) }\end{array}$ & 27.365 & 15.628 & 29.749 \\
\hline $\begin{array}{l}\text { Total land } \\
\text { area declared } \\
\text { protected } \\
\text { natural area } \\
\text { (km²) }\end{array}$ & 117,50 & 1,28 & 0 \\
\hline $\begin{array}{l}\text { Cultural assets } \\
\text { catalogued with } \\
\text { the highest level } \\
\text { of protection }\end{array}$ & 1 & 5 & 2 \\
\hline
\end{tabular}

\section{Results}

\subsection{Institutionalized heritage}

The values established by laws for the protection and conservation of heritage determine what assets and spaces comply with the specific criteria defined as "exceptional" by institutions. These assets and spaces then come to require administrative approval for inclusion into the public-managed catalogues that exist at different levels. In this, governments are responsible for "protecting and enhancing the historical, cultural and artistic treasure" of Spain (article 35 of the Spanish Constitution), as well as "the protection and enhancement of landscape and the historical-artistic heritage of Andalusia and [...] its monumental, archaeological and scientific heritage" (Statute of Autonomy of Andalusia). To this end, different cataloguing tools have been launched by the responsible for cultural heritage, as well as those charged with the protection of natural heritage in Sierra de Cádiz (e.g. at state and regional 
levels). Although there are many catalogues that effect the district nowadays, in this study we have addressed to those linked to some law related to heritage protection and safeguarding.

\subsubsection{Institutionalised Cultural Heritage}

In Sierra de Cádiz, there are 43 immovable resources that are categorized as Assets of Cultural Interest (BIC), which is the highest category of protection inside of Spanish legislation. Similar to the regional and state levels, most of these assets are monuments ${ }^{1}$, which include several castles, fortresses or walls protected in $1949^{2}$, and then incorporated into the current law in $1985^{3}$, and to the General Catalogue of the Andalusian Historical Heritage in 19914. Concerning the case study, there are 5 BIC's in Olvera, 2 in Setenil de las Bodegas, and 1 in Grazalema, with a Historical Complex in each municipality while the remainder are catalogued as Monuments. According to Pérez (2016), the legal form of Historical Complex represents urban spaces catalogued as settlement units of urban, landscape and territorial nature. Nevertheless, the author claims that in Sierra de Cádiz this administrative declaration basically responds to a reduced vision focused on a historical assessment. Additionally, there is no presence of other typologies with more holistic values such as Heritage Zone, which is defined in the current regional Law ${ }^{5}$.

Table 3: Cultural resources declared an Asset of Cultural Interest (BIC)

\begin{tabular}{|c|c|c|c|}
\hline Municipality & Denomination & Legal typology & Date of disposal \\
\hline Grazalema & $\begin{array}{l}\text { Grazalema Historic Site } \\
\text { - Centro Histórico de } \\
\text { Grazalema }\end{array}$ & Historical Complex & 08/07/2003 \\
\hline \multirow{5}{*}{ Olvera } & $\begin{array}{l}\text { Olvera Historic Site - } \\
\text { Conjunto Histórico Artístico } \\
\text { de Olvera }\end{array}$ & Historical Complex & $13 / 04 / 1983$ \\
\hline & Castle - Castillo & Monument & $25 / 06 / 1985$ \\
\hline & $\begin{array}{l}\text { Medieval Wall - Muralla } \\
\text { urbana }\end{array}$ & Monument & $25 / 06 / 1985$ \\
\hline & $\begin{array}{l}\text { Castle of Vallehermoso } \\
\text { - Castillo de Vallehermoso }\end{array}$ & Monument & $25 / 06 / 1985$ \\
\hline & $\begin{array}{l}\text { Ancient Convent of Our } \\
\text { Lady of Caños Santos } \\
\text { - Antiguo Convento de Ntra. } \\
\text { Sra. de Caños Santos }\end{array}$ & Monument & $18 / 09 / 2001$ \\
\hline \multirow[t]{2}{*}{$\begin{array}{l}\text { Setenil de } \\
\text { las Bodegas }\end{array}$} & $\begin{array}{l}\text { Setenil de las Bodegas } \\
\text { Historic Site - Conjunto } \\
\text { Histórico Artístico de } \\
\text { Setenil de las Bodegas }\end{array}$ & Historical Complex & $22 / 01 / 1985$ \\
\hline & Castle - Castillo & Monument & $25 / 06 / 1985$ \\
\hline
\end{tabular}

In terms of intangible cultural heritage, a huge number of rituals, expressions, craft, and gastronomic traditions are amongst the most significant heritage items in Andalusia, and, more specifically, in Sierra de Cádiz. In rural societies, as is the case here, there are many intangible manifestations. Some of them are shared by several municipalities, while others have an essentially local identity. Nevertheless, due to the relatively late recognition of the intangible heritage in Spanish legislation ${ }^{6}$, catalogues dedicated to it are few in number. In Andalusia, the Andalusian Institute of Historic Heritage has registered 57 elements from the district in the Inventory of Intangible Heritage in Andalusia, of which 11 are located in Grazalema, 3 in Olvera, and 4 in Setenil de las Bodegas. While in the first case they represent a heterogeneous mix of practices, every record in Setenil de las Bodegas is about Easter, while they all are linked to the celebration of a pilgrimage in the case of Olvera. 
Table 4: Intangible cultural heritage registered in the Inventory of Intangible Heritage of Andalusia

\begin{tabular}{|c|c|}
\hline Municipality & Denomination \\
\hline \multirow{11}{*}{ Grazalema } & Cheese production - Elaboración de quesos \\
\hline & Bull Monday - Lunes del Toro \\
\hline & Fights between the Moors and Christians - Luchas de Moros y Cristianos \\
\hline & Pottery - Alfarería \\
\hline & Chair production - Elaboración de sillas \\
\hline & Shearing - Esquileo a Tijeras \\
\hline & Wicker chair production - Elaboración de sillas con anea \\
\hline & Feast day of Our Lady of Carmel - Fiestas de la Virgen del Carmen \\
\hline & Local holiday of St. Anthony of Padua - Feria de San Antonio de Padua \\
\hline & Major Festivals of Grazalema - Fiestas Mayores de Grazalema \\
\hline & Pilgrimage of St. Isidro Labrador - Romería de San Isidro Labrador \\
\hline \multirow{3}{*}{ Olvera } & The Monday of Quasimod Pilgrimage - Romería del Lunes de Quasimodo \\
\hline & The Monday of Cake Function - Elaboración de la Torta del Lunes \\
\hline & Monday's Turnover Event - Elaboración del Hornazo del Lunes \\
\hline \multirow{4}{*}{$\begin{array}{l}\text { Setenil de las } \\
\text { Bodegas }\end{array}$} & Holy Thursday - Jueves Santo \\
\hline & Holy Friday - Viernes Santo \\
\hline & Holy Saturday - Sábado Santo \\
\hline & Easter Sunday - Domingo de Resurrección \\
\hline
\end{tabular}

\subsubsection{Natural Heritage}

Because of its mountainous location, Sierra de Cádiz has an environmental richness that is embodied in the cataloguing of two of the Andalusia's most important Nature Parks due to their geology, vegetation or climate (Cobos, 2016). There are also two Nature Sites, two Nature Reserves, a Nature Monument and two Biosphere Reserves declared by UNESCO. However, only three of these spaces extend over the municipalities in our current study: The Peñón de Zaframagón in Olvera, that was declared a Nature Reserve in 1989, and Sierra de Grazalema declared as Spain's first Biosphere Reserve in 1977 and Nature Park in 1984. All such resources are included in the Network of Protected Natural Spaces of Andalusia (RENPA), launched in 1989 as the largest inventory of protected natural spaces in Andalusia and which currently include the figures established in regional, state and European regulations.

Table 5: Nature areas registered in the Andalusian Network of Natural Heritage

\begin{tabular}{|l|l|c|}
\hline Municipality & \multicolumn{1}{|c|}{ Denomination } & \multicolumn{1}{|c|}{$\begin{array}{c}\text { Date of } \\
\text { disposal }\end{array}$} \\
\hline \multirow{2}{*}{ Grazalema } & $\begin{array}{l}\text { Sierra de Grazalema Biosphere Reserve - Reserva de la Biosfera Sierra } \\
\text { de Grazalema }\end{array}$ & $22 / 01 / 1977$ \\
\cline { 2 - 3 } & $\begin{array}{l}\text { Sierra de Grazalema Nature Park - Parque Natural Sierra de } \\
\text { Grazalema }\end{array}$ & $12 / 02 / 1984$ \\
\hline \multirow{2}{*}{ Olvera } & $\begin{array}{l}\text { Peñón de Zaframagón Nature Reserve - Reserva Natural Peñón de } \\
\text { Zaframagón }\end{array}$ & $27 / 07 / 1989$ \\
\hline
\end{tabular}




\subsubsection{Landscape Heritage}

The landscape of Grazalema and the landscape of Setenil de las Bodegas are amongst the five from Sierra de Cádiz that have recently been included in the Andalusian Inventory of Landscapes of Cultural Interest. The cataloguing documentation provided highlights the outstanding quality of these spaces, pointing to their history, complex urbanization and the defensive character of their exceptional monuments. Moreover, a study of landscape heritage reveals the extensive network of linear infrastructure created by livestock farmers and the movements of trade throughout history, as well as other obsolete infrastructure like railway lines that, in places, have been adapted for outings on foot, bicycle or horse due to their safety and comfort (Aycart, 2001). In this way, Sierra de Cádiz currently has a total of 1,103 kilometres of livestock trails that not only link natural and cultural heritage, as well as different villages, but also human beings and nature. There is certainly also a need to distinguish The Green Way of La Sierra, an eco-touristic project based on the restoration of an old railway track along with the rehabilitation of some train stations, which was the first project of tis kind completed at the national level.

Table 6: Landscape elements declared by regional legislation

\begin{tabular}{|l|l|}
\hline Municipality & Denomination \\
\hline Grazalema & $\begin{array}{l}\text { The Grazalema Landscape of Cultural Interest - Paisaje de Interés Cultural de } \\
\text { Grazalema }\end{array}$ \\
\hline Olvera & The Green Way of La Sierra - Vía Verde de La Sierra \\
\hline $\begin{array}{l}\text { Setenil de } \\
\text { las Bodegas }\end{array}$ & $\begin{array}{l}\text { The Setenil de las Bodegas Landscape of Cultural Interest - Paisaje de Interés Cultural } \\
\text { de Setenil de las Bodegas }\end{array}$ \\
\hline
\end{tabular}

\subsection{Heritage in the construction of the tourism image}

Sierra de Cádiz plays an important role as a pole of attraction for visitors since the discovery of this area in travel literature during the $18^{\text {th }}$ and $19^{\text {th }}$ centuries, when the perception of Spain by the European aristocracy changed (Freixa, 1991; Barke \& Towner, 1996; Carrère-Lara, 2001). At that time, the villages in this district were considered models of a homogenous architectural organization and places where the modest houses of whitewashed facades sit on slopes of sparse anthropisation. According to the Landscape Laboratory of the Andalusian Institute of Historic Heritage, these villages are "the main referent of one of the more widely distributed images of Andalusia, the White Villages, making the district one of the most representative samples of Andalusian character" (Fernández et al., 2010, p.535). Over time, this image transformed from being a qualitative feature recognized by the foreigners to a projection of the land assumed by the locals. Thus, it became the tourism image showed by administrations responsible for tourism promotion.

The quantitative analysis of materials edited by the Provincial Council of Tourism of Cádiz, which is the organism responsible for tourism promotion in the province, reveals that cultural assets account for more than half of the visual representations included in brochures, guides and videos until April, 2019. References to historic complexes have been highly repeated by this entity (i.e. 21.88 percent of total representations), as well as medieval buildings (i.e. more than 10.43 percent of the analysed images, mainly characterized by castles, fortresses or walls). On the other hand, visual references to intangible items barely account for 10 percent of them. Likewise, natural spaces did not surpass 17.30 percent of the total studied, being represented by the Sierra de Grazalema Nature Park in more than half of the cases, thanks to the vast span of this space in the district and the large number of municipalities encompassed by it. Finally, 31.30 percent of the projected images are related to Landscapes of Cultural Interest. 
Figure 2: Heritage about the district of Sierra de Cádiz as projected in promotional material edited by the Provincial Council of Tourism (1982-2019)

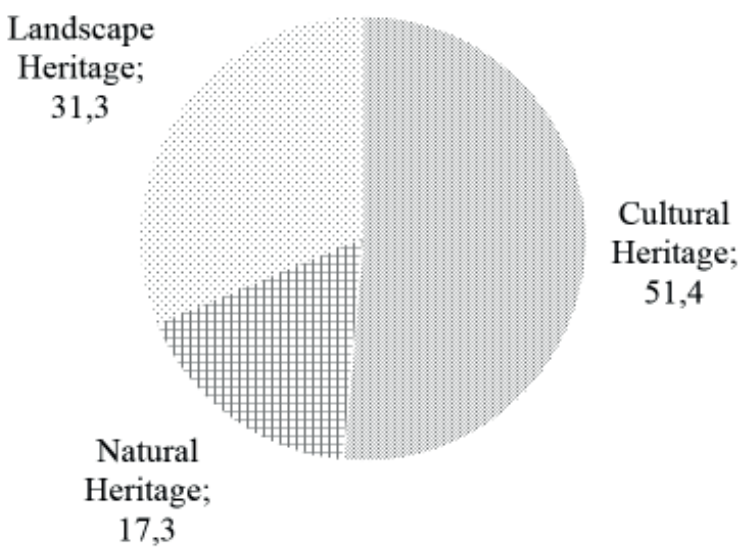

A semiotic analysis of the images included in local level tourism promotional materials demonstrates that immovable assets are the most common elements in the promotion of the destination, and especially its historic complexes. Nevertheless, the Sierra de Grazalema Nature Park is the most repeated item, as it accounts for over half of the total publicity produced in Grazalema. It is remarkable, however, how some of the most common immovable assets in the promotional materials have not been institutionally protected, such as of the Church of Our Lady of Incarnation in Olvera, which is the building repeated most in local level promotion at in this case study. This analysis draws attention to the fact that intangible resources used in the promotional materials are very few in number.

Table 7: Heritage resources shown in promotional materials edited by administrations at the local level in Grazalema, Olvera and Setenil de las Bodegas (2007-2019)

\begin{tabular}{|l|l|c|c|c|}
\hline Municipality & \multicolumn{1}{|c|}{ Denomination } & Times & Munic. \% & District \% \\
\hline Grazalema & $\begin{array}{l}\text { Sierra de Grazalema Nature } \\
\text { Park - Parque Natural Sierra de } \\
\text { Grazalema }\end{array}$ & 33 & 56.90 & 9.12 \\
\hline $\begin{array}{l}\text { Setenil de } \\
\text { las Bodegas }\end{array}$ & $\begin{array}{l}\text { Setenil Historic Site - Conjunto } \\
\text { histórico de Setenil }\end{array}$ & 12 & 36.36 & 5.83 \\
\hline Grazalema & $\begin{array}{l}\text { Grazalema Historic Site - Conjunto } \\
\text { histórico de Grazalema }\end{array}$ & 8 & 13.79 & 2.21 \\
\hline Olvera & $\begin{array}{l}\text { Olvera Historic Site - Conjunto } \\
\text { histórico de Olvera }\end{array}$ & 12 & 12.63 & 2.02 \\
\hline Olvera & $\begin{array}{l}\text { Church of Our Lady of Incarnation } \\
- \text { Iglesia Ntra. Sra. de la } \\
\text { Encarnación }\end{array}$ & 12 & 12.63 & 2.02 \\
\hline $\begin{array}{l}\text { Setenil de } \\
\text { las Bodegas }\end{array}$ & $\begin{array}{l}\text { Hermitage of San Benito - Ermita } \\
\text { de San Benito }\end{array}$ & 4 & 11.58 & 1.94 \\
\hline Olvera & $\begin{array}{l}\text { Olvera's Landscape - Paisaje de } \\
\text { Olvera }\end{array}$ & 11 & 10.53 & 1.69 \\
\hline Olvera & Castle - Castillo & 10 & & 12 \\
\hline
\end{tabular}




\begin{tabular}{|c|c|c|c|c|}
\hline Olvera & $\begin{array}{l}\text { Sanctuary of Our Lady of the } \\
\text { Remedies - Santuario de Ntra. Sra. } \\
\text { de los Remedios }\end{array}$ & 9 & 9.47 & 1.52 \\
\hline $\begin{array}{l}\text { Setenil de } \\
\text { las Bodegas }\end{array}$ & Castle - Castillo & 3 & 9.09 & 1.46 \\
\hline $\begin{array}{l}\text { Setenil de } \\
\text { las Bodegas }\end{array}$ & $\begin{array}{l}\text { Church of Our Lady of Incarnation } \\
\text { - Iglesia Ntra. Sra. de la } \\
\text { Encarnación }\end{array}$ & 3 & 9.09 & 1.46 \\
\hline Grazalema & $\begin{array}{l}\text { Urban Site of Benamahoma - } \\
\text { Conjunto urbano de Benamahoma }\end{array}$ & 5 & 8.62 & 1.38 \\
\hline Olvera & $\begin{array}{l}\text { Green Way of La Sierra - Vía verde } \\
\text { de la Sierra }\end{array}$ & 8 & 8.42 & 1.35 \\
\hline Grazalema & $\begin{array}{l}\text { Benamahoma's Landscape - Paisaje } \\
\text { de Benamahoma }\end{array}$ & 4 & 6.90 & 1.11 \\
\hline $\begin{array}{l}\text { Setenil de } \\
\text { las Bodegas }\end{array}$ & $\begin{array}{l}\text { Hermitage of San Sebastián } \\
\text { - Ermita de San Sebastián }\end{array}$ & 2 & 6.06 & 0.97 \\
\hline $\begin{array}{l}\text { Setenil de } \\
\text { las Bodegas }\end{array}$ & $\begin{array}{l}\text { Setenil Town Hall - Ayuntamiento } \\
\text { de Setenil }\end{array}$ & 2 & 6.06 & 0.97 \\
\hline $\begin{array}{l}\text { Setenil de } \\
\text { las Bodegas }\end{array}$ & $\begin{array}{l}\text { House of The Dame of Setenil } \\
\text { - Casa de la Damita de Setenil }\end{array}$ & 2 & 6.06 & 0.97 \\
\hline $\begin{array}{l}\text { Setenil de } \\
\text { las Bodegas }\end{array}$ & Coracha Mina - Coracha Mina & 2 & 6.06 & 0.97 \\
\hline Grazalema & $\begin{array}{l}\text { Grazalema's Landscape - Paisaje } \\
\text { de Grazalema }\end{array}$ & 3 & 5.17 & 0.83 \\
\hline Olvera & $\begin{array}{l}\text { Peñón del Sagrado Corazón rock } \\
\text { - Peñón del Sagrado Corazón }\end{array}$ & 4 & 4.21 & 0.67 \\
\hline Grazalema & $\begin{array}{l}\text { Church of Our Lady of Aurora } \\
\text { - Iglesia de Ntra. Sra. de la Aurora }\end{array}$ & 2 & 3.45 & 0.55 \\
\hline Grazalema & $\begin{array}{l}\text { Church of San José - Iglesia de San } \\
\text { José }\end{array}$ & 2 & 3.45 & 0.55 \\
\hline Olvera & $\begin{array}{l}\text { Ancient Convent of Our Lady of } \\
\text { Caños Santos - Antiguo Convento } \\
\text { de Ntra. Sra. de Caños Santos }\end{array}$ & 3 & 3.16 & 0.51 \\
\hline Olvera & $\begin{array}{l}\text { Peñón de Zaframagón Nature } \\
\text { Reserve - Reserva Natural Peñón } \\
\text { de Zaframagón }\end{array}$ & 3 & 3.16 & 0.51 \\
\hline Olvera & $\begin{array}{l}\text { Elaboration of cured porks } \\
\text { - Elaboración de chacinas }\end{array}$ & 3 & 3.16 & 0.51 \\
\hline Olvera & $\begin{array}{l}\text { La Cilla's Building - Edificio de la } \\
\text { Cilla }\end{array}$ & 3 & 3.16 & 0.51 \\
\hline Olvera & $\begin{array}{l}\text { Olvera Town Hall - Ayuntamiento } \\
\text { de Olvera }\end{array}$ & 3 & 3.16 & 0.51 \\
\hline $\begin{array}{l}\text { Setenil de } \\
\text { las Bodegas }\end{array}$ & Holy Thursday - Jueves Santo & 1 & 3.03 & 0.49 \\
\hline $\begin{array}{l}\text { Setenil de } \\
\text { las Bodegas }\end{array}$ & Holy Friday - Viernes Santo & 1 & 3.03 & 0.49 \\
\hline $\begin{array}{l}\text { Setenil de } \\
\text { las Bodegas }\end{array}$ & $\begin{array}{l}\text { Setenil de las Bodegas's Landscape } \\
\text { - Paisaje de Setenil de las Bodegas }\end{array}$ & 1 & 3.03 & 0.49 \\
\hline Olvera & Medieval Wall - Muralla urbana & 2 & 2.11 & 0.34 \\
\hline
\end{tabular}




\begin{tabular}{|l|l|c|c|c|}
\hline Olvera & $\begin{array}{l}\text { Elaboration of the Monday Cake } \\
- \text { Elaboración de la Torta del Lunes }\end{array}$ & 2 & 2.11 & 0.34 \\
\hline Olvera & $\begin{array}{l}\text { Olvera's Cemetery - Cementerio de } \\
\text { Olvera }\end{array}$ & 2 & 2.11 & 0.34 \\
\hline Olvera & $\begin{array}{l}\text { Old Laundry Site of Pino - } \\
\text { Lavadero de Pino }\end{array}$ & 2 & 2.11 & 0.34 \\
\hline Olvera & Corpus Christi - Corpus Christi & 2 & 2.11 & 0.34 \\
\hline Olvera & Carnival - Carnaval & 2 & 2.11 & 0.34 \\
\hline Grazalema & $\begin{array}{l}\text { Fights between Moorish and } \\
\text { Christians - Luchas de Moros y } \\
\text { Cristianos }\end{array}$ & 1 & 1.72 & 0.28 \\
\hline Olvera & $\begin{array}{l}\text { Castle of Vallehermoso - Castillo de } \\
\text { Vallehermoso }\end{array}$ & 1 & 1.05 & 0.17 \\
\hline Olvera & $\begin{array}{l}\text { Pilgrimage of the Monday of } \\
\text { Quasimodo - Romería del Lunes de } \\
\text { Quasimodo }\end{array}$ & 1 & 1.05 & \\
\hline
\end{tabular}

\subsection{The social appreciation of heritage}

During the process of drawing up the Strategic Tourism Plan of Olvera 2017-2020, the Strategic Tourism Plan of Setenil de las Bodegas 2017-2020 and the Tourist Quality Plan of Grazalema-Benamahoma 2018-2023, a survey about social needs was launched. It gave residents the opportunity to express their points of view on different topics related to tourism and local heritage both online and in-person.

A question included in these surveys asked for their main heritage resources, which was aimed at exploring the perceptions of local residents. In the context of creating a strategic plan that would affect the whole community, people are more proactive, which may contribute to higher survey response rates. Thus, a total of 411 valid questionnaires were filled out by locals. In Grazalema, 161 valid answers were obtained, which was 8.37 percent of the total population. The total number of valid questionnaires was around 133 in Olvera, which is 1.84 percent of their population over 16 years of age. Finally, 117 questionnaires were completed in Setenil de las Bodegas, which represents 4.80 percent of the population. In the context of gender status, 187 participants were male and 224 were female. So, in general terms, the responses to this specific question were brought together according to similar concepts in Grazalema, while they remained grouped by distinct items in Olvera, and remained more convergent in Setenil de las Bodegas.

Table 8: Heritage resources cited more than once in the survey

\begin{tabular}{|l|c|l|c|l|c|}
\hline \multicolumn{1}{|c|}{ Grazalema } & \multicolumn{2}{c|}{ Olvera } & \multicolumn{2}{c|}{ Setenil de las Bodegas } \\
\hline \multicolumn{1}{|c|}{ Answers } & $\%$ & \multicolumn{1}{c|}{ Answers } & $\%$ & \multicolumn{1}{c|}{ Answers } & $\%$ \\
\hline $\begin{array}{l}\text { Natural } \\
\text { heritage in } \\
\text { general }\end{array}$ & 29.57 & $\begin{array}{l}\text { Landscape and } \\
\text { context }\end{array}$ & 19.37 & $\begin{array}{l}\text { Cave streets } \\
\text { and the urban } \\
\text { landscape }\end{array}$ & 47.76 \\
\hline $\begin{array}{l}\text { Conservation } \\
\text { of the urban } \\
\text { pattern }\end{array}$ & 12.17 & $\begin{array}{l}\text { Mix of Castle } \\
\text { and Church } \\
\text { monuments }\end{array}$ & 14.14 & Historic site & 14.43 \\
\hline Churches & 10.43 & Historic site & 12.04 & Castle & 10.45 \\
\hline $\begin{array}{l}\text { Landscape and } \\
\text { context }\end{array}$ & 6.96 & Natural context & 10.47 & $\begin{array}{l}\text { Church of Our } \\
\text { Lady of the } \\
\text { Incarnation }\end{array}$ & 7.96 \\
\hline Holidays & 6.96 & Gastronomy & 9.95 & Chapels & 6.47 \\
\hline Gastronomy & 6.96 & Castle & 9.42 & Natural context & 4.98 \\
\hline
\end{tabular}




\begin{tabular}{|l|c|l|l|l|c|}
\hline Trails & 5.22 & $\begin{array}{l}\text { Church of Our } \\
\text { Lady of the } \\
\text { Incarnation }\end{array}$ & 8.38 & Scenic lookouts & 2.99 \\
\hline $\begin{array}{l}\text { Pinsapar } \\
\text { Endogenous } \\
\text { forest }\end{array}$ & 5.22 & $\begin{array}{l}\text { Green Way of } \\
\text { La Sierra }\end{array}$ & 8.38 & Medieval wall & 1.99 \\
\hline $\begin{array}{l}\text { Sierra de } \\
\text { Grazalema } \\
\text { Nature Park }\end{array}$ & 4.35 & Hospitality & 2.62 & Easter & 1.49 \\
\hline $\begin{array}{l}\text { Popular } \\
\text { handcrafts }\end{array}$ & 3.48 & Weather & 2.62 & Gastronomy & 1.49 \\
\hline Industry & 3.48 & $\begin{array}{l}\text { Sanctuary of } \\
\text { Our Lady of the } \\
\text { Remedies }\end{array}$ & 1.57 & & \\
\hline History & 2.61 & $\begin{array}{l}\text { Peñón de } \\
\text { Zaframagón } \\
\text { Nature Reserve }\end{array}$ & 1.05 & & \\
\hline Hospitality & 2.61 & & & & \\
\hline
\end{tabular}

The pristine nature which exists around the village of Grazalema is the main resource for nearly a third of the respondents from this municipality. They pointed to some concrete items, such as the Nature Park Sierra de Grazalema or the Pinsapar zone, as spaces of great value, reaching a total of 39.14 percent of the responses. Likewise, the conservation of the urban pattern of this village is another of the most important resources for 12.17 percent of citizens, together with an immovable cultural heritage represented by churches, which exceeds 10 percent of responses. The landscape is cited by almost 7 percent of the participants, while the paths scarcely exceed 5.22 percent of the responses. Holidays and gastronomy, which are typical intangible elements, obtained 7 percent of the replies, while popular handicrafts barely went beyond 3.48 percent.

In Olvera, 2 out of every 10 respondents valued the landscape as the main heritage resource in the municipality. Little more than 14 percent cited the building complex consisting of the Church of Our Lady of the Incarnation and the Castle. Located above the houses, these draw the village's skyline and stand forth as the main attraction. One out of every three responses highlighted the landscape of Olvera although it is the only one in the study that was not catalogued in public inventories. In terms of immovable cultural heritage, these two buildings are the most common references, with 9.42 percent and 8.38 percent of the responses, respectively. Meanwhile, more than 12 percent of participants indicated the Historic Site. The Green Way of La Sierra occupied 8.38 percent of replies, while the unique natural protected space in the municipality, the Peñón de Zaframagón Nature Reserve, appeared only twice.

The characteristic Cave Streets and cliffs in the urban landscape of Setenil de las Bodegas are the main resource for almost half of the responders in this municipality. Far behind those, the Historic Site received 14.43 percent of responses. With respect to immovable cultural heritage, the Castle, the Church, the religious Chapels and the Medieval Wall were the most highlighted assets as cited by participants, accounting for 26.87 percent of the total replies. Local intangible heritage is represented by Easter traditions as well as local gastronomy, each comprising a very low percentage of responses.

\section{Discussion}

Through the analysis of primary and secondary informational sources, we discover that the Sierra de Grazalema Nature Park, which was the first nature park to be protected in Sierra de Cádiz, is considered the main resource by citizens of Grazalema, a municipality of 2000 people whose entire surface is occupied by this space. These people, indeed, make their living from the exploitation of the resources in this natural area, through livestock or agricultural production, as well as tourism. As such, this space continues to be the most remarkable visual element in the district's tourism promotional material, with more than half of its marketing references citing natural protected areas both locally and provincially. 
All of this data confirms the existence of specific correlations between the criteria being used, both by local authorities (i.e. responsible for tourism, like heritage management) and society. Nevertheless, while administrative authorities in charge of the environment highlight the preservation of indigenous values, tourism agents use the image of the area as a representation of idealistic landscapes of beauty according to the canons of the Victorian alpine aesthetic.

Institutionalized historic complexes are also some of the most important referential landmarks for citizens, having become some of the most widely used resources in the tourism marketing as well. This indicates that both local residents and foreigners (i.e. reflected in the induced image created by tourism administrations) give crucial importance to those symbolic features considered to be central to a community's livelihood. These places have been catalogued by administrations in order to conserve their unique identities. For its part, landscape is one of the most used resources in tourism promotion. It also stands out as being one of the most valued items for locals, regardless of whether or not they have been recognized at the institutional level. These conclusions show that people have largely overcome the dualism between nature and culture as defined by its protective institutions.

Moreover, although immovable assets began to be catalogued by heritage protection administrations decades ago, the difference between the appreciations of protected versus unprotected buildings by both the local population as well as their tourism administrations is negligible. This fact is further substantiated by the administered questionnaires as well as in the semiotic analysis of tourism's promotional materials, which shows that that many unprotected assets enjoy a higher profile than those others that have been prioritized by supra-local administrations responsible for culture.

Here, it is also worth emphasizing the limited importance that intangible heritage has in luring tourists in this particular district. Likewise, popular opinion gives scarce importance to festivities, except in those cases where they are considered to be events that attract visitors. This confirms that people give greater value to intangible heritage considered to be remarkable to foreigners. This fact demonstrates that tourist activity may indeed affect the way people understand the place where they live. It also means that tourism and social perspectives on heritage may progress faster than their administrative frameworks, incorporating integrative and holistic perspectives that are far beyond the inherited viewpoints of cultural and environmental laws.

\section{Conclusions}

To determine how the different significances of heritage function in a specific geographical area, a methodological model was developed. This new model was based on (i) an in-depth evaluation of the concept of heritage at a theoretical level, and (ii) an empirical analysis applied to a specific case study. Firstly, the study contributed to the identification of three different significances of heritage in the current socio-cultural environment (e.g. institutionalized strategies, the tourist approach, and social appreciation). Secondly, empirical analysis allowed us to see how these factors relate to (and impact) a rural context where tourism has a strong economic dimension. The implementation of this model in other spaces would provide an opportunity to explore the prevalence of repeated patterns in the understanding of heritage in different contexts. This is possible because segmented administrative structures are similar all over the globe, and tourist industry uses equivalent visual tools for promoting destinations since the Enlightenment. This is especially relevant in the current capitalist context, which is characterized by the primacy of economic values over identity. It therefore becomes particularly pertinent in Europe, where development policies have emphasized tourism development as a solution to agricultural and demographic crises in isolated areas. Rural areas have weaker economic structures and tourism has a greater capacity for spatial (com)modification, which may have a tremendously negative impact.

The analysis of dissonances and similarities between the three significances of heritage in an Andalusian rural district reveals that there are some links between the popular vision of heritage and the discourse of tourism institutions, especially at the supra-local level. In both social perception and tourism promotion, landscape is a priority subject as it represents a huge integrative vision of the land. Nonetheless, this category is not legally protected by administrations, which still continue to prioritise isolated immovable assets.

This also means that economic approaches to heritage have taken hold in rural communities above and beyond their institutional discourses. It is in this way that the tourism image projected by institutions, which is based on the configuration of a simplified representation of the land with easily recognizable concepts, has the potential of making a difference to the way locals perceive their own context. This 
influence is increasingly closer to the notion of scenery because of the incorporation of reading that are more aesthetically inclined. This may involve museumification processes, which essentially transform heritage into a tourist spot. The destination is therefore built according to the wishes of potential visitors, which may entail important socio-territorial consequences.

Updating the legislative and policy frameworks drives the social views on heritage, as they are conditioned by traditional dichotomies and dualism as well as the inherence of old values in cataloguing. As a result, this process favours the fact that there are different laws, plans or cataloguing tools for both cultural and natural assets and spaces, making it more difficult to assign them with innovative perspectives of heritage.

Only three municipalities were researched in this case study, and so the results presented here should not be considered generalizable. Future lines of research may set out to explore the possibility of expanding the breadth and scope of investigation by developing new analyses that follow the practical model proposed here.

\section{Bibliography}

Agudo Torrico, J. 1999. Cultura, patrimonio etnológico e identidad. PH Boletín del Instituto Andaluz del Patrimonio Histórico, 26, 36-45.

Aguilar Criado, E., Merino Baena, D. \& Migens Fernández, M. 2003. Cultura, políticas de desarrollo y turismo rural en el ámbito de la globalización. Horizontes Antropológicos, 9 (20), 161-183.

Albarrán, J.D. 2020. Patrimonio territorial, políticas públicas y turismo: un análisis escalar. Los casos de Andalucía y La Sierra de Cádiz (Doctoral thesis). Complutense University of Madrid, Madrid, Spain.

Albers, P. \& James, W.R. 1988. Travel photography. A methodological approach. Annals of Tourism Research, 15, 134-158.

Alebaki, M. \& Koutsouris, A. 2019. Wine tourism destinations across the Life-Cycle: A comparison of Northern Greece, Peloponnese and Crete. In M. Sigala \& R. Robinson (coord.), Management and Marketing of wine detinations: Theory, practice and cases (pp. 463-482). Palgrave, UK.

Almirón, A., Bertoncello, R. \& Troncoso, C. 2006. Turismo, Patrimonio y Territorio. Una discusión de sus relaciones a partir de casos en Argentina. Estudios y Perspectivas en Turismo, 15, 101-124.

Alvarado-Sizzo, I., Mínguez García, M.C. \& López López, Á. 2018. Representaciones visuales de los destinos turísticos a través de Internet: el caso de Valladolid (México). Pasos Revista de Turismo y Patrimonio Cultural, 16 (2), 335-351.

Amat Montesinos, X. 2018. El patrimonio territorial y paisajístico de Petrer. In Petrer Arqueología y Museo, Museos Municipales en el MARQ (pp. 12-23). Alicante, Spain: Museo Arqueológico de Alicante.

Andreu, L., Bigné, J.E. \& Cooper, C. 2000. Projected and Perceived Image of Spain as a Tourist Destination for British Travellers. Journal of Travel \& Tourism Marketing, 9 (4), 47-67.

Arefi, M. 1999. Non-place and Placelessness as Narratives of Loss: Rethinking the Notion of Place. Journal of Urban Design, 4, 179-193.

Ariño Villarroya, A. 2002. La expansión del patrimonio cultural. Revista de Occidente, 250, 129-150.

Aycart Luengo, C. 2001. Vías Verdes, reutilización de ferrocarriles en desuso para movilidad sostenible, ocio y turismo. Informes de la Construcción, 53 (475), 17-29.

Ballart Hernández, J. \& Juan I Tresserras, J. 2008. Gestión del patrimonio cultural. Barcelona, Spain: Ariel.

Barke, M. \& Towner, J. 1996. Exploring the History of Leisure and Tourism in Spain. In M. Barke, J. Towner \& M. Newton (coord.), Tourism in Spain: Critical Issues (pp. 3-34). Wallingford, UK: CAB International.

Barthes, R. 2002. Mitologías. Ciudad de México, Mexico: Siglo XXI ediciones.

Batista Sánchez, E., Serrano Leyva, B. \& Pérez Ricardo, E.C. 2020. Bibliometric study of tourism destination image in Science Direct. Revista Interamericana de Ambiente y Turismo, 16 (1), 97-105.

Berger P. \& T. Luckmann 1986. La construcción social de la realidad (Cap. III). Buenos Aires, Argentina: Amorrortu.

Bertoncello, R. 2015. Patrimonio y Turismo, una Relación en Tensión. Aportes para el Estudio en Argentina. In Y. Salomão (ed.), Patrimônio Cultural Plural (pp. 5-19). Belo Horizonte, Brasil: Arraes Editores Ltda.

Bianchi, R. 2017. The political economy of tourism development: A critical review. Annals of Tourism Research, 70, 88-102. 
Bridgewater, P. \& Rotherham, I.D. 2019. A critical perspective on the concept of biocultural diversity and its emerging role in nature and heritage conservation. People and Nature, 1, 291-304.

Britton, S. 1990. Tourism, capital, and place: towards a critical geography of tourism. Environmental and Planning D: Society and Space, 9, 451-478.

Buck, R. 1977. The Ubiquitous Tourist Brochure: Explorations in its Intended and Unintended Uses. Annals of Tourism Research, 4 (4), 195-207.

Bustos Cara, R. \& Pinassi Mayoral, A. 2017. The development \& management of territorial heritage. The recent experience of Argentina. In F. Manero Miguel \& J.L. García Cuesta (coord.) Territorial Heritage \& Spatial Planning. A Geographical Perspective (pp. 277-298). Navarra, Spain: Thomson Reuters. The Global Law Collection.

Calderón Calderón, B. \& García Cuesta, J.L. 2016a. Patrimonio y territorio en España: fundamentos y estrategias para la gestión de la cultura territorial. In Manero Miguel, F. \& García Cuesta, J.L. (coord.), Patrimonio cultural y desarrollo territorial-Cultural heritage \& territorial Development (pp. 51-105). Navarra, Spain: Ed. Thomsom Reuters-Aranzadi.

Calderón Calderón, B. \& García Cuesta, J.L. 2016b. Sources and forms of territorial heritage. International Journal of Humanities and Cultural Studies, 3, 2141-2157.

Capel, H. 2014. El patrimonio natural y territorial. De la protección a la gestión y regeneración del paisaje cultural. Zarch, 2, 8-41.

Carrera Díaz, G. 2005. La evolución del patrimonio (inter)cultural: políticas culturales para la diversidad”. Cuadernos del Patrimonio Histórico Andaluz, 17, 14-29.

Carrère Lara, E. 2001. La imagen desértica de Andalucía a través de los relatos de los viajeros románticos franceses: ¿mito o realidad?. Cuadernos de Ilustración y Romanticismo, 9, 29-46.

Carta, M. 2010. Patrimonio territoriale, descrizione strutturale, statuti del territorio, scenari di transformazione e progetti integratis. In J. Muntañola (ed.), Hacia un urbanismo alternative. Arquitectonics. Barcelona, Spain: Mind, Land \& Society.

Castillo Ruiz, J. 2007. El futuro del patrimonio histórico: la patrimonialización del hombre. Revista Electrónica e-rph, 1.

Castrillo Romón, M.A. \& Tremiño San Emeterio, C. 1998. Territorio y patrimonio en la IX Conferencia del Consejo Académico Iberoamericano: ideas y experiencias para una nueva cultura disciplinar. Ciudades: Revista del Instituto Universitario de Urbanística de la Universidad de Valladolid, 4, 13-29.

Castro Gabriel, L.P.M. \& Rodrigues Soares, J.R. 2017. El uso de la imagen turística en la promoción de los destinos patrimoniales. Tourism and Hospitality International Journal, 8 (2), 51-67.

Cobos Rodríguez, L.M. 2016. Territorio y patrimonio arqueológico de La Sierra de Cádiz: un proyecto por concluir. PH Boletín del Instituto Andaluz del Patrimonio Histórico, 89, 48-59.

Cors I Iglesias, M., Gómez Martín, M.B. \& Armesto López, X.A. 2018. La apuesta por el patrimonio histórico-artístico en el turismo de montaña. El caso del pirineo catalán. Scripta Nova, 22 (588).

Dann, G. 1996. Tourists Images of a Destination: An Alternative Analysis. Journal of Travel and Tourism Marketing, 5, 41-55.

Diekmann, A. 2018. Tourism and Heritage: a Dialogue of Deaf-Still not Solved. In Sitcon 2018 (pp. 3-7). Belgrade, Serbia.

Dilley, R.S. 1986. Tourist Brochures and Tourist Images. The Canadian Geographer, 30, 59-65.

Doctor, A.M. 2011. El itinerario como herramienta para la puesta en valor turístico del patrimonio territorial. Cuadernos de Turismo, 27, 273-289.

Donaire J.A. \& Galí, N. 2011. La imagen turística de Barcelona en la comunidad de Flickr. Cuadernos de Turismo, 27, 291-303.

Edelheim, J.R. 2007. Hidden messages: a polysemic reading of tourist brochures. Journal of Vacation Marketing, 13, 5-17.

Feria Toribio, J.M. 2010. Patrimonio territorial y desarrollo sostenible: un estudio comparativo en Iberoamérica y España. Estudios Geográficos, 71 (268), 129-159.

Feria Toribio, J.M. 2013. El patrimonio territorial: algunas aportaciones para su entendimiento y puesta en valor. Revista electrónica e-rph, 12, 1-25.

Fernández Cacho, S. 2019. La dimensión paisajística en la gestión del patrimonio cultural en España. Estudios Geográficos, 80.

Fernández Cacho, S., Fernández Salinas, V., Hernández León, E., López Martín, E., Quintero Morón, V., Rodrigo Cámara, J.M. \& Zarza Balluguera, D. 2010. Paisajes y patrimonio cultural en Andalucía. Tiempo, usos e imágenes. Seville, Spain: Instituto Andaluz del Patrimonio Histórico, Consejería de Cultura, Junta de Andalucía. 
Fernández, G. \& Guzmán Ramos, A. 2004. El Patrimonio Histórico-Cultural revalorizado en el marco de un desarrollo sustentable del turismo. Tandil, Argentina: Universidad Nacional del Centro de la Provincia de Buenos Aires.

Fernández, R. 1998. Topofilia americana. Hacia un concepto de patrimonio ambiental en América Latina. Ciudades: Revista del Instituto Universitario de Urbanística de la Universidad de Valladolid, 4, 49-71.

Florido Trujillo, G. 2013. El patrimonio territorial en el Plan de Ordenación del Territorio de Andalucía: indefiniciones y dificultades para un conocimiento preciso. Boletín de la AGE, 63, 173-201.

Freixa Lobera, C. 1991. La imagen de España en los viajeros británicos del siglo XVIII. Barcelona, Spain: University of Barcelona.

García Quevedo, K.M. \& Mercado López, E. 2019. De reflexión a propuesta metodológica sobre la imagen de territorios turísticos y su patrimonio. La ruta de Don Vasco. Journal of Tourism and Heritage Research, 1, 260-272.

Gómez Mendoza, J. 2013. Del patrimonio paisaje a los paisajes patrimonio. Documents d'Anàlisi Geogràfica, 59(1), 5-20.

González-Varas Ibáñez, I. 2014. Las ruinas de la memoria: Ideas y conceptos para una (im)posible teoría del patrimonio cultural. Ciudad de México, Mexico: Siglo XXI Editores.

Goodrich, J.N. 1978. The Relationship Between Preferences for and Perceptions of Vacation Destinations: Application of a Choice Model. Journal of Travel Research, 17 (2), 8-13.

Graham, B., Ashworth, G \& J. Tunbridge 2000. A Geography of Heritage. Power, Culture and Economy. London, UK: Arnold Publishers.

Gunn, C. 1988. Vacationscape, Designing Tourist Regions. New York, USA: V.N. Reinhold.

Harvey, D.C. 2019. Heritage pasts and heritage presents: temporality, meaning and the scope of heritage studies. In S. Watson, A.J. Barnes \& K. Bunning (ed.), A museum studies approach to heritage. New York, USA: Routledge.

Hernández Ramírez, J. 2007. La parte por el todo. Imágenes de Andalucía emitidas por organismos públicos. In La imagen de Andalucía en el discurso turístico. Seville, Spain: Factoría de Ideas, Centro de Estudios Andaluces

Hernández Ramírez, J. 2008. La imagen de Andalucía en el Turismo. Seville, Spain: Fundación Centro de Estudios Andaluces, Consejería de la Presidencia, Junta de Andalucía.

Hiernaux, D. 2002. Turismo e imaginarios. Cuaderno de Ciencias Sociales, 123, 7-36.

Huete Alcocer, N. \& López Ruiz, V.R. 2019. The role of destination image in tourist satisfaction: the case of a heritage site. Economic Research-Ekonomska Istraživanja.

ICOMOS 1999. International Cultural Tourism Charter. 12th General Assembly. Mexico.

Jull, M. 2015. Tourism and the European Union, Recent trends and policy developments. Brussels, Belgium: European Parliamentary Research Service.

Katahenggam, N. 2019. Tourist perceptions and preferences of authenticity in heritage tourism: visual comparative study of George Town and Singapore. Journal of Tourism and Cultural Change, 18 (4:3), 71-385.

Lasso De La Vega, C. 2006. La imagen de Andalucía en el discurso publicitario. Seville, Spain: Centro de Estudios Andaluces, Consejería de la Presidencia.

Laven, D.N. 2015. Heritage development and community resilience: Insights for the era of climate change. In D.C. Harvey \& J. Perry (ed.), The Future of Heritage as Climates Change: Loss, Adaptation and Creativity (pp. 167-180). London, UK: Routledge

Laven, D.N., Mitchell, N.F. \& Wang, D. 2005. Examining Conservation Practice at the Landscape Scale. In D. Laven, N.F. Mitchell \& D. Wang (ed.), Conservation at the Landscape Scale (pp. 5-9). Hancock, Michigan, US: The George Wright Forum.

Laven, D.N., Wall-Reinius, S. \& Fredman, P. 2015. New Challenges for Managing Sustainable Tourism in Protected Areas: An Exploratory Study of the European Landscape Convention in Sweden. Society \& Natural Resources, 28 (10), 1-18.

Lerivray, B. 1975. Guides bleus, guides vertes et lunettes roses. Paris, France: Du Chef.

Llull Peñalba, J. 2005. Evolución del concepto y de la significación social del patrimonio cultural. Arte, Individuo y Sociedad, 17, 175-204.

López Lara, E., Tribak, A., Baali, H. \& El Bezzari, L. 2017. Turismo, patrimonio territorial y desarrollo en el medio Atlas Nororiental (Marruecos). Cuadernos de Turismo, 40, 389-404.

Maderuelo, J. 2006. Paisaje y Pensamiento. Madrid, Spain: Abada. 
Manero Miguel, F. \& García Cuesta, J.L. 2016. Cultura, Patrimonio y Desarrollo. In F. Manero Miguel \& J.L. García Cuesta (coord.) Patrimonio Cultural y Desarrollo Territorial. Cultural Heritage \& Territorial Development (pp. 17-24). Thomson Reuters Aranzadi, Cizur Menor.

Martín De La Rosa, B. 2003. La imagen turística de las regiones insulares: las islas como paraísos. Cuadernos de Turismo, 11, 127-137.

Martín Jiménez, M.I. 2016. Patrimonio y paisaje en España y Portugal. Del valor singular a la integración territorial. Boletín de la AGE, 71, 347-374.

Martínez Yáñez, C. 2008. Patrimonialización del territorio y territorialización del patrimonio. Cuadernos de Arte de la Universidad de Granada, 39, 251-266.

Mata Olmo, R. 2008. El paisaje, patrimonio y recurso para el desarrollo territorial sostenible. Conocimiento y acción pública. ARBOR Ciencia, Pensamiento y Cultura, 184, 155-172.

Matteucci, X. \& Önder, I. 2018. Using drawings to explore images of Vienna. Tourism Analysis, 23 (4), 517-531.

Maurín Álvarez, M. 2011. Huella, memoria y patrimonio territorial de la minería española. Una síntesis cartográfica. Ería, 86, 187-214.

Medina, F.X. 2017. Reflexiones sobre el patrimonio y la alimentación desde las perspectivas cultural y turística. Anales de Antropología, 51 (2), 106-113.

Mehmood, S., Liang, C. \& Gu, D. 2018. Heritage Image and Attitudes toward a Heritage Site: Do They Really Mediate the Relationship between User-Generated Content and Travel Intentions toward a Heritage Site?. Sustainability, 10 (4403).

Méndez Baiges, M. 2017. El estilo del relax y la imagen pop de la Costa del Sol. In F. Mangone \& A. Pizza, A. (ed.), Immaginare il Mediterraneo (pp. 101-110). Naples, Italy: Artstudio Paparo.

Milman, A. 2011. The symbolic role of postcards in representing a destination image: the case of Alanya, Turkey. International Journal of Hospitality \& Tourism Administration, 12, 144-173.

Molina De La Torre, I. \& Pascual Ruiz-Valdepeñas, M.H. 2016. El patrimonio territorial en el marco del desarrollo local. In Manero Miguel, F. \& García Cuesta, J. L. (coords.), Patrimonio Cultural y Desarrollo Territorial. Cultural Heritage \& Territorial Development (pp. 371-417). Cizur Menor, Navarra, Spain: Thomson Reuters Aranzadi.

Monteserín Abella, O. 2008. Turismo y desarrollo territorial: los planes de dinamización turística en la interpretación y puesta en valor del territorio (Doctoral thesis). Complutense University of Madrid, Madrid, Spain.

Mulero Mendigorri, A. 2015. Hacia la gestión integrada del patrimonio en clave territorial: un análisis crítico a partir de la experiencia andaluza. Investigaciones Geográficas, 63, 69-84.

Novo Espinosa De Los Monteros, G., Osorio García, M., Torres Nafarrate, J. \& Esquivel Solís, E. 2013. Viajes, actuantes, escenarios e interacciones: un análisis de la publicidad de los destinos, a partir de sus semánticas visuales. Investigaciones Turísticas, 6, 27-46.

Ortega Valcárcel, J. 1998. Patrimonio territorial: el territorio como recurso cultural y económico. Ciudades: Revista del Instituto Universitario de Urbanistica de la Universidad de Valladolid, 4, 33-48.

Ozouf-Marignier, M.V. 2010. Le langage de l'aménagement en France: de la pathologie des territoires au territoire-ressource. In N. Ortega, J. García \& Mollá Ruiz-Gómez (ed.), Lenguajes y visiones del paisaje y del territorio (pp. 327-341). Madrid, Spain: AGE.

Pearce, D. 1989. Tourist Development. New York, USA: Longman.

Perelló, J.L. 2006. La imagen del destino turístico en el proceso global de satisfacción del consumidor: Metodología para su estudio. Habana, Cuba: ETUR.

Pérez Cano, M.T. 2016. Reflexiones sobre los BIC conjuntos históricos: La Sierra de Cádiz. PH Boletín del Instituto Andaluz del Patrimonio Histórico, 89, 34-47.

Petriou, E., Alebaki, M. \& Von Bergmann-Winberg, M.L. 2018. Entrepreneurship in times of crisis: A resilience perspective on the Greek wine sector. In C. Karlsson, C. Silander \& D. Silander (ed.), Governance and Political Entrepreneurship in Europe Promoting Growth and Welfare in Times of Crisis (pp. 208-226). Cheltenham, UK: Elgar Publishing.

Picazo, P. \& Moreno-Gil, S. 2017. Analysis of the projected image of tourism destinations on photographs: A literature review to prepare for the future. Journal of Vacation Marketing, 25, 3-24.

Picón Prado, E., Varela Mallou, J., Rial Boubeta, A. \& Braña Tobío, T. 2013. Habi: una herramienta para la representación de la imagen de un producto o servicio. Revista Española de Investigación de Marketing ESIC, 17 (1), 83-104.

Pillet Capdepón, F. 2011. El turismo de interior y el patrimonio territorial en Castilla-La Mancha. Cuadernos de Turismo, 27, 725-741. 
Pillet Capdepón, F. 2012. El turismo de interior en la España peninsular: el patrimonio territorial como destino turístico. Boletín de la Asociación de Geógrafos Españoles, 59, 345-366.

Pine B.J. \& Gilmore J.H. 1998. Welcome to the Experience Economy. Harvard Business Review, 97-105.

Pine B.J. \& Gilmore J.H. 2011. The experience economy. Brighton, Massachusetts, USA: Harvard Business Review Press.

Piramanayagam, S., Rathore, S. \& Seal, P.P. 2020. Destination image, visitor experience, and behavioural intention at heritage centre. Anatolia, 31(2), 211-228.

Prats Canals, L. 1997. Antropología y patrimonio. Barcelona, Spain: Ariel.

Prats Canals, L. 2005. Concepto y gestión del patrimonio local. Cuadernos de Antropología Social, 21, 17-35.

Pritchard, A. \& Morgan, N.J. 2001. Culture, identity and tourism representation: marketing Cymru or Wales?. Tourism Management, 22, 167-179.

Regional Ministry of Tourism, Regeneration, Justice and Local Administration 2020. Registro de Turismo de Andalucía. From https://www.juntadeandalucia.es/organismos/turismoregeneracionjusticiayadministracionlocal/areas/turismo/registro-turismo.html

Relph, E. 1976. Place and placelessness. London, UK: Pion Limited.

Relph, E. 2000. Author's Response: Plaec and Placelessness in a New Context. Progress in Human Geography, 24, 617-619.

Richardson, S. \& Crompton, J.L. 1988. Cultural variations in perceptions of vacation attributes. Tourism Management, 9, 128-136.

Rodríguez Cámara, J.M., Díaz Iglesias, J.M., Fernández Cacho, S., Fernández Salinas, V., Hernández León, E., Quinterio Morón, V., González Sancho, B. \& López Martín, E. 2012. Registro de paisajes de interés cultural de Andalucía. Criterios y metodología. Revista PH, 81, 64-75.

Rodríguez Pérez, C. \& Sevilla Álvarez, J. 2017. El patrimonio territorial y paisajístico de Leitariegos: de la mirada intelectual a la primera acción oficial contemporánea. Boletín de la Asociación de Geógrafos Españoles, 74, 61-92.

Román López, E. \& González Loyola, M.S. 2019. Tecnologías de información geográfica para la gestión del patrimonio territorial. Los paisajes culturales de la sal en Chile. Identidades: territorio, cultura, patrimonio, 8.

San Martín Guitiérrez, H. \& Rodríguez Del Bosque, I.A. 2008. Exploring the cognitive-affective nature of destination image and the role of psychological factors in its formation. Tourism Management, 29, 263-277.

San Martín Guitiérrez, H., Rodríguez Del Bosque, I.A. \& Vázquez Casielles, R. 2006. Análisis de la imagen en turismo mediante técnicas estructuradas y no estructuradas: implicaciones competitivas para los destinos turísticos. Revista asturiana de economía, 35, 69-91.

San Martín Gutiérrez, H. 2005. Estudio de la imagen de destino turístico y el proceso global de satisfacción: adopción de un enfoque integrador. Santander, Spain: University of Cantabria.

Santana Talavera, A. 2003. Turismo cultural, culturas turísticas. Horizontes Antropológicos, 9(20), 31-57.

Santos Solla, X.M. 2008. Paisaje e identidad en la promoción de la imagen de los destinos turísticos. In Espacios Turísticos: mercantilización, paisaje e identidad (pp.195-206). Alicante, Spain: University of Alicante.

Silva Pérez, R. \& Fernández Salinas, V. 2017. El nuevo paradigma de patrimonio y su consideración con los paisajes. Documents d'Anàlisi Geogràfica, 63(1), 129-151.

Silva Pérez, R. 2009. Agricultura, paisaje y patrimonio territorial. Los paisajes de la agricultura vistos como patrimonio. Boletín de la AGE, 49, 309-334.

Smith, L. 2006. Uses of heritage. London, UK: Routledge.

Suárez Japón, J.M. 1982. El hábitat rural de La Sierra de Cádiz. Cadiz, Spain: Diputación Provincial de Cádiz.

Thurot, J. \& Thurot, G. 1983. The Ideology of Class and Tourism: Confronting the Discourse of Advertising. Annals of Tourism Research, 10, 173-189.

Torres Camacho, J. 2017. Los premios de embellecimiento: paisaje e identidad turística local. In N. López, R. Cañada, G. Gómez, J.A. Palacios \& C. Mínguez (coord.), XXV Congreso de Geógrafos Españoles: Naturaleza, territorio y cultural en un mundo global. Madrid: Spain.

Torres, R.M. \& Momsen, J.D. 2005. Gringolandia: The construction of a New Tourist Space in Mexico. Annals of the Association of American Geographers, 95(2), 314-335.

Troitiño Vinuesa, M.Á. \& Troitiño Torralba, L. 2015. Territorio y Sistemas Patrimoniales: la Región Urbana de Madrid. Ciudad y territorio: Estudios territoriales, 48(84), 255-273. 
Troitiño Vinuesa, M.Á. \& Troitiño Torralba, L. 2018. Visión territorial del patrimonio y sostenibilidad del turismo. Boletín de la AGE, 78, 212-244

Troitiño Vinuesa, M.Á. 1998. Patrimonio arquitectónico, cultura y territorio. Ciudades: Revista del Instituto Universitario de Urbanistica de la Universidad de Valladolid, 4, 95-104.

Troitiño Vinuesa, M.Á. 2000. Turismo y desarrollo sostenible en ciudades históricas. Desafíos y Oportunidades. XIII Cursos de verano de la Universidad Complutense de Madrid. Turismo, Patrimonio Cultural y Recuperación Urbana. San Lorenzo de El Escorial, Spain.

Troitiño Vinuesa, M.Á. 2003. Ciudades históricas y turismo sostenible. A Distancia, 1, 47-51.

Troitiño Vinuesa, M.Á. 2011. Territorio, patrimonio y paisaje: desafíos de una ordenación y gestión inteligentes. Ciudad y Territorio: Estudios territoriales, 43, 561-569.

Troncoso, C.A. 2010. Patrimonio, turismo y lugar: selecciones, actores y lecturas en torno a La Quebrada de Humahuaca (Jujuy, Argentina) como Patrimonio de la Humanidad. Cuadernos de Turismo, 25, 207-227.

Troncoso, C.A. 2013. Política turística y patrimonial en la ciudad de Salta, Argentina. Disonancias en la protección y usos del centro histórico. Estudios y perspectivas en turismo, 22, 1002-1024.

Un (1992). The Rio Declaration on Environment and Development. Rio de Janeiro, Brasil: The United Nations Conference on Environment and Development.

UNWTO \& UNESCO 2015. Siem Reap Declaration on Tourism and Culture. Siem Reap, Camboia.

UNWTO \& UNESCO 2017. Mascate Declaration on Tourism and Culture: Fostering Sustainable Developmnet. Oman, Oman.

UNWTO \& UNESCO 2018. Istanbul Declaration on the Protection of World Heritage. Istanbul, Turkey. UNWTO 1985. Tourism Bill of Rights e Tourist Code. Sofia, Bulgaria.

Urry, J. 2002. The Tourist Gaze: Leisure and Travel in Contemporary Societies. London, UK: Sage.

Vahí Serrano, A. 2010. El territorio y la orientación comercial. La salvaguarda del patrimonio territorial en las Comunidades Autónomas de España. Anales de Geografía, 30(1), 139-161.

Velasco González, M. 2007. Distintos instrumentos para un mismo fin. Los instrumentos de las políticas públicas como herramienta para el análisis. In VIII Congreso de Ciencia Política y de la Administración. Valencia, Spain.

Velasco González, M. 2009. Gestión turística del patrimonio cultural: enfoques para un desarrollo sostenible del turismo cultural. Cuadernos de Turismo, 23, 237-253.

Wall-Reinius, S. 2012. Wilderness and Culture: Tourist Views and Experiences in the Laponian World Heritage Area. Society \& Natural Resources, 25(7), 621-632.

Woodside, A.G. \& Lysonski, S. 1989. A General Model of Traveler Destination Choice. Journal of Travel Research, 27(4), 8-14.

Zwiers, S., Markantoni, M., \& Strijker, D. 2018. The role of change- and stability-oriented place attachment in rural community resilience: a case study in south-west Scotland. Community Development Journal, 53(2), 281-300.

\section{Notes}

1 A study completed about the General Catalogue of the Andalusian Historical Heritage reveals that the category of Monument is the most numerous at the regional level, accounting for $73.83 \%$ of the total. On the other hand, the new figures Heritage Zone and Picturesque Spot, with higher territorial values, barely reached $1.07 \%$ and $0.13 \%$ respectively. Even the category of Historic Complex is quite residual here (Albarrán, 2020).

2 Decree of 22 April 1949 about Protection of Spanish Castles. (BOE, nº 125, of 5 May 1949).

Law 16/1985, of 25 June, of Historic Spanish Wealth. (BOE, n ${ }^{\circ} 155$, of 29 June 1985).

Law 1/1991, of 3 July, of Historic Heritage in Andalusia. (BOJA, $n^{\circ} 59$, of 13 July 1991).

Law 14/2007, of 26 November, of Historic Heritage in Andalusia. (BOJA, $\mathrm{n}^{\circ} 248$, of 19 December 2007).

Law 10/2015, of 26 May, for the Safety of Intangible Cultural Heritage. (BOE, $\mathrm{n}^{\circ} 126$, of 27 May 2015).

Recibido:

$20 / 04 / 2020$

Reenviado:

$22 / 02 / 2021$

Aceptado:

$22 / 02 / 2021$

Sometido a evaluación por pares anónimos 